\title{
Transition from Educational Leadership to e- Leadership: A Data Analysis Report from TEI of Western Greece
}

\author{
Hera Antonopoulou \\ University of Patras \\ Patras, Greece \\ Constantinos Halkiopoulos \\ University of Patras \\ Patras, Greece \\ Olympia Barlou \\ University of Patras \\ Patras, Greece \\ Grigorios N. Beligiannis \\ University of Patras \\ Patras, Greece
}

\begin{abstract}
Over the last two decades, there is growing up interest on research in educational leadership. Current conditions favour a shift towards a form of leadership "that shapes an environment built into collaborative culture and open to improvements, trials and challenges. Higher education leadership is of interest. According to research, universities are not completely out of this need for effective leadership as they face similar challenges with any other organization and the effective development of university leadership is important to the normal function and success of higher education. Among the different forms of educational leadership, the implementation of transformational leadership in higher education is recognized as the most appropriate, as it focuses on the division of leadership among academic members who have enough abilities to manage collectively the range of leadership responsibilities required in different contexts. Transformational leadership academics can manage the university effectively, leading the organization to maximize organizational results. This view is also being reflected in our study, which focused on the degree of three specific leadership styles (transformation, trade and leadership to avoid or not lead) by members of the Senate of Technological Educational Institute of Western Greece. Our findings show that the leadership outcome has a strong positive correlation with transformational leadership and a large
\end{abstract}


negative correlation with passive - to avoid leadership, it was confirmed that the higher degree of transformational leadership implies greater efficiency and satisfaction for workers, and the high degree of transformational leadership co-exists with the great degree of implementation of digital leadership.

Keywords: Leadership, ICT; e-Leadership; e-skills; Data Analysis.

\section{Introduction}

Nowadays, Europe needs sufficient electronic leaders capable of leading to significant innovative achievements and exploiting the progress of information and communication technologies (ICT). Growth in all organizations and teachers depends on identifying and effectively (Bryman, 2007) exploiting innovation opportunities, and this in turn requires good digital leading skills (Katuna, 2019).

Digital leading skills consist of the set of knowledge and skills that allows an individual to begin and lead ICT-related innovative patterns at all stages of an organization.

Electronic Leadership (Mahajan, 2011) or Digital Competence (Morgan \& Manganaro, 2016) is the achievement of an ICT-based target through human resource guidance and the use of ICT. Holders of electronic leadership skills (Digital Leaders) are highly valued in organizations of all categories.

The "e-Leader" is defined as a person who has the guidance of interdisciplinary staff and develops an ability of the following parameters:

- Innovating strategic business and operational models

- Utilization of digital trends

- Vision and amelioration of marketing achievements and

- Impact of shareholders beyond borders (operational, geographical)

During 2012, empirica, IDC (premier global provider of market intelligence, advisory services, and events for the IT and IT LEADERS) and INSEAD (a graduate business school with campuses in Europe consistently ranked among the best business schools in the world) worked together on a study for the European Commission's Directorate General Enterprise and Industry (Rybnicek et al., 2019). The goal of the study, entitled e-Leadership: Skills for Competitiveness and Innovation. A particular focus of the study was on eleadership skills.

The Digital Leadership (Samson, 2009) Initiative based on the conclusions of the INSEAD study, "European e-Competence Curricula Development Guidelines" comprising policy and institutional guidelines across the full e-skills domain. The policy guidelines are to a) encourage industry to strengthen personal development and b) provide incentives for life-long learning e.g. by inclusion in performance rating. 
The institutional guidelines for successful curriculum development recommend:

- Boosting motivation in potential students

- Associate and provide expertise with industry and potential employers

- elaboration of syllabuses while linking to other curricula promoting interdisciplinary collaborations

- Up-to-date graduate knowledge of the modern business environment

- Continuous reformulation and improvement of curriculum design

The way of amelioration digital leadership skill provision takes full account of the above-mentioned parameters. The digital leadership Initiative the INSEAD ideas to the level of a portfolio of new curricula delivering e-leadership skills, embedded in a sustainable (Pihie et al., 2011), living quality assurance framework. This framework ensures an ongoing match between course content and innovation and leadership requirements across economic sectors and all sizes of organization (Robinson et al., 2015).

One of the main elements of leadership (Woods, 2005) that contributes to its effectiveness, is the leader's style and more specifically the behavior shown by the leader leading the university community in effective organizational directions (Black, 2015; Braun et al., 2009).

In this light, there is need to engrave e-skills that characterize a leader and more precisely an e-leader. Mobility, cloud technology knowledge, big data analysis, social media technologies, IOT, customer experience (CXIT), Information Security Systems are some prerequisites e-skills of an e-leader. The purpose of this paper is to investigate the following e-skills in the field of Educational Organizations:

a) The degree of appearance of three specific leadership styles (transformative, transactional, avoidance) and specifically the members of the Senate of Western Greece TEI (Presidents of Chambers, Deans, Rector, Deputy Rector)

b) If members of the Senate have the profile of the digital leader independently from the leadership style if they have the necessary eskills that would characterize them as digital leaders? In particular, conceptual delimitation, identification and understanding of the concept of leadership in general, and more specifically in Tertiary education as a function of the administration, will be made, as well as an investigation into the degree of the appearance of certain leadership styles in the departments of the four TEI Western Greece Schools.

It will also record the specific skills that the Leaders must have in order to be digital and the degree of their appearance to the members of the TEI Senate of Western Greece. 


\section{Research Questions}

Research cases can be summarized as follows:

- Which leadership style prevails?

- Are the style and leadership outcome differentiated according to the leader's gender and years of service in administrative position?

- Does the leadership style relate to the knowledge and application of specific e-skills?

- Does the direction of the School (Theoretical - Applied - Other) relate to the presence of digital leaders?

\section{Methods}

\section{Data Collection}

To complete this investigation will follow the procedures provided for quantitative surveys, namely, the use of literature for defining research questions, data collection using scales that contain specific questions with defined and measurable range of responses and data analysis with statistical scientific methods (Cresswell, 2011).

An overview survey and correlation survey option will be made. The survey is used to collect (Cohen, Manion \& Morrison, 2008). The correlation research monitors relations between two or more variables in order to determine the impact of a data at a specific time, to capture and describe the circumstances and to investigate the relationships between the variables in the other and helps in predicting results (Cresswell, 2011).

\section{Sample}

The method to be followed for collecting data is to fill in an anonymous questionnaire. This is a method that is considered to be the most appropriate for collecting data about opinions, attitudes, beliefs and values. The data to be collected will be quantified, statistically analyzed and deduced from the analysis of conclusions, which are generalizable in larger population groups. The anonymity of responses may contribute to the honesty of the subjects' responses (Cohen, et al., 2008, Vambuka, 2007).

The performance of the questionnaire to members of the Senate will be implemented through a unique completion link through Google's Google Form application. The information to be collected will be coded and analyzed using a statistical program, namely the SPSS program.

The distribution of all variables will be examined with the Kolmogorov-Smirnov test and, as appropriate, parametric or non-parametric methods of analysis will be applied. The comparison of demographic-descriptive data will be done either 
by spreading analysis or by Pearson's $x 2$ analysis. The correlation between the variables will be done with regression analysis.

\section{Data Collection Tool}

A questionnaire with closed-ended questions, consisting of three parts, will be used to collect the survey data. The first part contains questions related to the demographic data of the sample, such as gender, age, years of service in a university position, category of subject, class (theoretical, applied, etc.) (Arsenault, 2007).

The second part consists of the Multifactor Leadership Questionnaire (MLQ), which was proposed by Bass in 1985 and has since been revised several times. His latest version (MLQ Form - 5x) was made by Avolio and Bass in 1995 and is a useful tool for researchers and consultants. The MLQ has been published in many publications, languages and in many countries around the world (Drugus et al., 2014).

The MLQ (Multifactor Leadership Questionnaire) measuring the full extent of leadership style (Avolio \& Bass, 2011), is the Transformational Leadership (Transformational Leadership), the transactional leadership (Transactional Leadership) and passive - to avoid leadership (passive - Avoidant Leadership).

The third part consists of questions related to the knowledge and application of e-skills according to the INSEAD study (B-UP).

ICT trends are expected to affect the demand for more specialized digital skills and skills related to Digital Leadership over the next decade. The key question now is whether technological advances impact the digital skills of a Digital Leader (Shafer, 2016).

The selection of the most important trends was based on the following criteria (Lighton, 2018; Jenkins \& Andenoro, 2016; Bolden et al., 2008):

- Mobility: The rapid growth of mobile devices and technologies in the wider technology market as well as the exploitation and application of new mobile technologies in the business education environment.

- Cloud Computing: ICT software and services with flexibility and ondemand business-education models.

- Big Data Analysis: The technological and business challenge of the time for more efficient management huge amounts of data, both business and non-business, with the use of new technology structures to their best advantage allowing for high speed recording, discovery and / or analysis.

- Social Media Technologies: Social Media knowledge inside and outside of the Enterprise-Organization, the implementation of digital marketing techniques and the facilitation of knowledge sharing.

- Internet of Things: The Internet of Things is of great social and economic importance as it has impacts on areas such as consumer products, transportation, industrial and auxiliary components, sensors and other 
everyday objects that are interconnected and can improve the way they are connected. our work but also our daily life.

- Customer Experience: IT investments required to manage and optimize the client (or citizen) experience in an organization. This new area reflecting the growing convergence of innovative IT technologies into services based on client experience made by business managers / managers.

- IT Security: Without doubt, there is high dependence of businesses in Europe from digital systems and also the point is that there are obstacles in the connected environments because of their complexity. Therefore, there is a great demand and diffusion of software and other assets to guarantee system security at all stages (Hofmeyer et al., 2015).

Moving further on the details of defining the skills of Digital Leadership (Figure 1 ), there are real skills and competencies that combine to define the Digital Leader based on the three skill areas:

a) Digital skills,

b) Business skills and

c) Strategic leadership skills.

Moving further on the details of defining the skills of Digital Leadership.

\section{Results}

The responses of the survey participants were appropriately coded and entered into a database of the SPSS 18 statistical software. Each column of this database represents the total answers to a question and each line represents all the answers of a respondent. The questions asked through the questionnaire are variables that can be categorized and ordered.

Various methods of statistical analysis, both descriptive and inductive, are used for each category of variables. Specifically, for the categorical variables (demographic characteristics, digital properties) were used:

Descriptive methods: Frequency - percentage tables, percentage bars and pie charts.

For the operative variables (leadership, leadership outcome, number of digital properties) were used:

Descriptive methods: minimum value, maximum value, mean value, standard deviation, average bar graphs.

Induction methods: Non-parametric Mann-Whitney statistical tests (to compare the averages of two independent samples), Kruskal-Wallis (to compare the averages of three or more independent samples) and Wilkoxon Signed Ranks Test (to compare averages two related samples). 
The possible correlation between the different enumeration variables was investigated through the Pearson linear correlation coefficient. Also, the possible dependence between the various operative variables was investigated through simple linear regression.

The credibility of the various ranges of questions about leadership style and leadership outcome was measured by the Cronbach's Alpha reliability index. Index values above 0.7 (or more than 0.6 according to various investigators) show satisfactory reliability.

For all assay tests of statistical tests, correlations and linear regressions, a significance level of $\alpha=0.05$ was used.

\section{Sample}

Table 1: Sample demographic characteristics $(\mathrm{N}=15)$

\begin{tabular}{lccc}
\hline & & $\begin{array}{c}\text { FREQUENCY } \\
(\mathbf{N})\end{array}$ & $\begin{array}{c}\text { PERCENTAGE } \\
(\mathbf{\%})\end{array}$ \\
\hline \multirow{2}{*}{ SEX } & Man & 11 & 73,3 \\
& Woman & 4 & 26,7 \\
\hline \multirow{2}{*}{ AGE } & $\mathbf{4 1 - 5 0}$ & 5 & 33,3 \\
& $\mathbf{5 1 - 6 0}$ & 7 & 46,7 \\
\hline \multirow{2}{*}{ WORK EXPERIENCE IN HIGHER } & $\mathbf{7 6 0}$ & 3 & 20,0 \\
EDUCATION & $\mathbf{6 - 1 0}$ & 1 & 6,7 \\
& $\mathbf{1 1 - 2 0}$ & 6 & 40,0 \\
\multirow{2}{*}{ WORK EXPERIENCE IN } & $\mathbf{> 2 0}$ & 8 & 53,3 \\
ADMINISTRATIVE POSITION & $\mathbf{0 - 3}$ & 6 & 40,0 \\
& $\mathbf{4 - 6}$ & 1 & 6,7 \\
& $\mathbf{7 - 9}$ & 5 & 33,3 \\
& $\mathbf{> 9}$ & 3 & 20,0 \\
\hline
\end{tabular}

The majority of respondents (Table 1) are men $(73.3 \%$ ), while about $1 / 4$ are women $(26.7 \%)$. As members of the senate, $46.7 \%$ of the respondents belong to the $51-60$ age group and $20 \%$ are over 60 years old. However, there is also $33.3 \%$ in the 41-50 age group. The sample members have many years of service in tertiary education, with $53.3 \%$ serving over 20 years. The same percentage is in administrative positions for more than 7 years (Figure 1). 

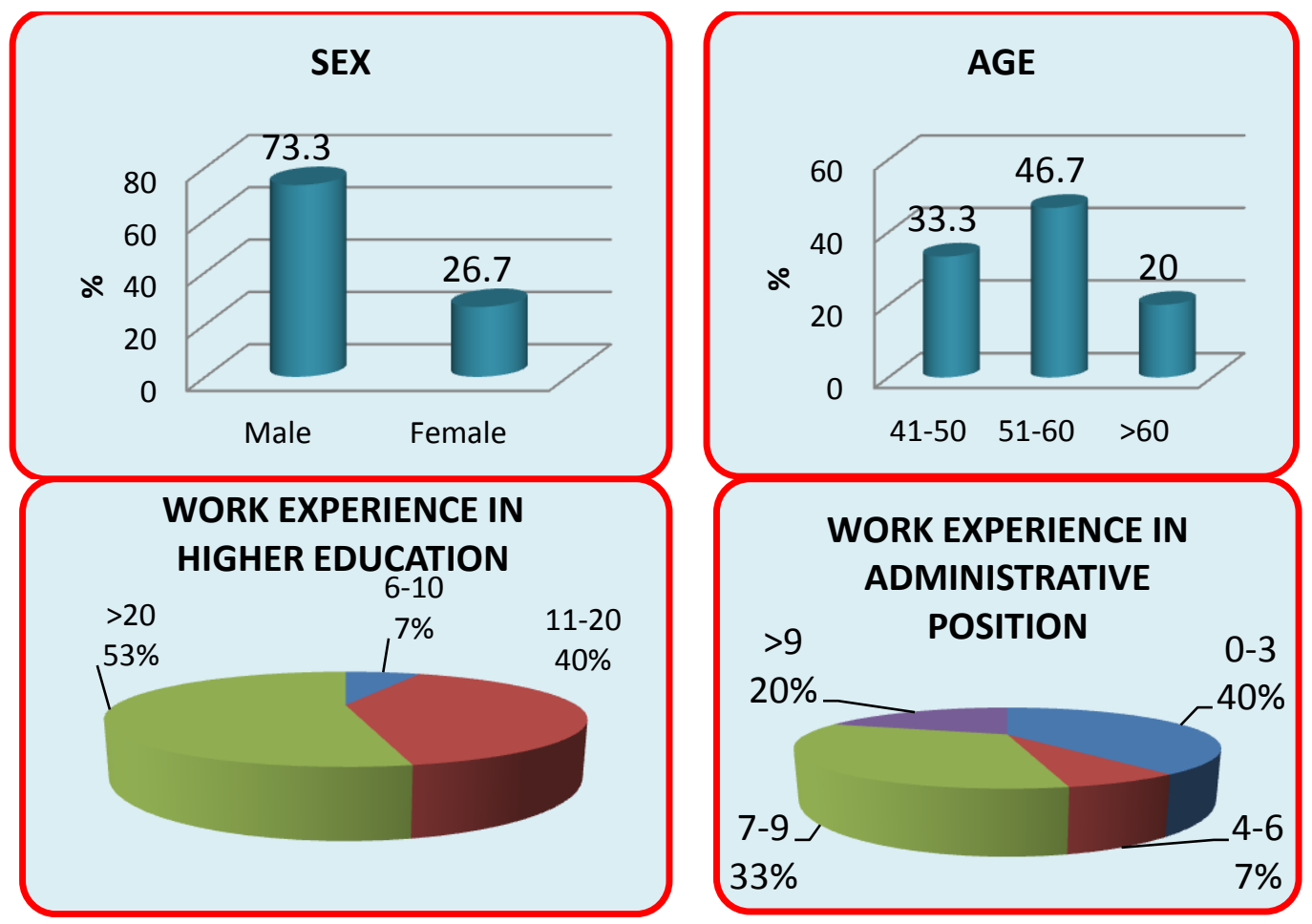

Figure 1: Sample Demographic Characteristics (N=15)

\section{Overview of Style Leadership}

Lead Multifactorial Leadership Questionnaire (MLQ) was used in order to evaluate leadership styles. Participants were called to capture an extent to that they present specific behaviors, with a scale from 1 (Not at all) to 5 (Almost always) answering 45 questions. Similarly, digital leadership was measured using 5 related questions.

For each respondent, we calculate the average of the responses pertaining to each leadership style, and an individual average score range of 1 - 5 can be obtained. The higher the score achieved, the more the leader style is exercised by the respondent (Figure 2).

The reliability of all scales is very satisfactory since Cronbach's Alpha has values of 0.660 (in the case of the Leadership) up to 0.911 (in the case of Transformational Leadership). Particularly in the case of digital leadership, Cronbach's Alpha amounts to 0.845. This fact allows us to think that the 5 questions that measure this particular leadership style belong to the same conceptual unity and can be represented by a new variable as an average of these 5 questions (Table 2). 
Table 2: Description of the examined variables

\begin{tabular}{lcccccc}
\hline & N & Min & Max & Mean & SD & $\begin{array}{c}\text { Cronbach's } \\
\text { Alpha }\end{array}$ \\
\hline Transformational leadership & 15 & 3,35 & 4,90 & 4,16 & 0,524 & 0,911 \\
\hline Trade leadership & 15 & 3,00 & 4,50 & 3,98 & 0,436 & 0,606 \\
\hline Passive to avoid leadership & 15 & 1,00 & 3,00 & 1,83 & 0,548 & 0,748 \\
\hline Leading leadership & 15 & 3,11 & 5,00 & 4,02 & 0,581 & 0,897 \\
\hline Digital leadership & 15 & 2,00 & 5,00 & 3,65 & 0,998 & 0,845 \\
\hline
\end{tabular}

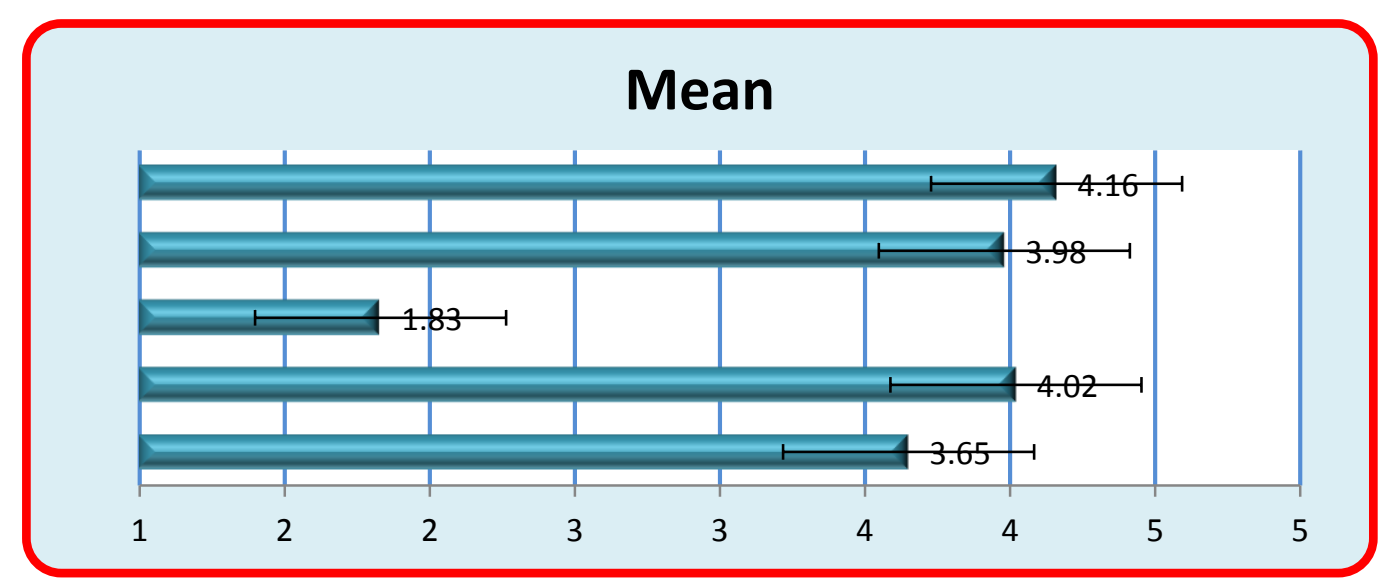

Figure 2: Levels of examined variables

We find that the respondents are very much involved in Transformation Leadership (4.16) and in Leadership Management (3.98) with a slightly lower frequency. The difference in the degree of exercise of these 2 leadership styles is non-statistically significant ( $\mathrm{p}>0.05)$.

On the contrary (Table 3), we notice that the participants in the survey avoid Passive - To avoid leadership $(1,83)$. In fact, this style is exerted at a statistically significantly lesser degree both in relation to the Transformation and the Economic Leadership ( $p<0.05)$.

Table 3: Investigation of differences between leadership styles

\begin{tabular}{|c|c|c|c|c|}
\hline & Mean & SD & Test & P-value \\
\hline Transformational leadership & 4,16 & 0,524 & \multirow{2}{*}{$\begin{array}{c}\text { Wilkoxon } \\
\text { Signed Ranks } \\
\text { Test } \\
\end{array}$} & \multirow{2}{*}{0,083} \\
\hline Trade leadership & 3,98 & 0,436 & & \\
\hline Transformational leadership & 4,16 & 0,524 & \multirow{2}{*}{$\begin{array}{c}\text { Wilkoxon } \\
\text { Signed Ranks } \\
\text { Test } \\
\end{array}$} & \multirow{2}{*}{$0,001^{* *}$} \\
\hline Passive to avoid leadership & 1,83 & 0,548 & & \\
\hline Trade leadership & 3,98 & 0,436 & $\begin{array}{c}\text { Wilkoxon } \\
\text { Signed Ranks } \\
\text { Test } \\
\end{array}$ & $0,001^{* *}$ \\
\hline
\end{tabular}




\section{Leadership styles based on demographic characteristics}

In order to determine whether the demographic characteristics impact statistically on the leadership style (Table 4), non-parametric statistical tests were conducted Mann-Whitney and Kruskal-Wallis.

Table 4: Leadership style - Sex

\begin{tabular}{|c|c|c|c|c|c|}
\hline Leadership style & Sex & Mean & SD & Test & P-value \\
\hline \multirow{2}{*}{ Transformational } & Male & 4,14 & 0,539 & \multirow{2}{*}{ Mann-Whitney } & \multirow{2}{*}{0,753} \\
\hline & Female & 4,21 & 0,553 & & \\
\hline \multirow{2}{*}{ Trade } & Male & 4,03 & 0,458 & \multirow{2}{*}{ Mann-Whitney } & \multirow{2}{*}{0,280} \\
\hline & Female & 3,81 & 0,375 & & \\
\hline \multirow{2}{*}{ Passive } & Male & 1,86 & 1,864 & \multirow{2}{*}{ Mann-Whitney } & \multirow{2}{*}{0,949} \\
\hline & Female & 1,75 & 1,750 & & \\
\hline \multirow{2}{*}{ Leading } & Male & 4,02 & 0,557 & \multirow{2}{*}{ Mann-Whitney } & \multirow{2}{*}{0,753} \\
\hline & Female & 4,03 & 0,734 & & \\
\hline \multirow{2}{*}{ Digital } & Male & 3,76 & 0,954 & \multirow{2}{*}{ Mann-Whitney } & \multirow{2}{*}{0,489} \\
\hline & Female & 3,35 & 1,204 & & \\
\hline
\end{tabular}

At first, we find that gender does not affect the extent to which each member of the senate engages in the research. Any differences presented are not statistically significant $(\mathrm{p}>0.05)$.

Table 5: Leadership styles: Age

\begin{tabular}{|c|c|c|c|c|c|}
\hline Leadership style & AGE & Mean & SD & Test & P-value \\
\hline \multirow{3}{*}{ Transformational } & $41-50$ & 4,14 & 0,572 & \multirow{3}{*}{ Kruskal-Wallis } & \multirow{3}{*}{0,794} \\
\hline & $51-60$ & 4,23 & 0,616 & & \\
\hline & $>60$ & 4,03 & 0,524 & & \\
\hline \multirow{3}{*}{ Trade } & $41-50$ & 4,03 & 0,358 & \multirow{3}{*}{ Kruskal-Wallis } & \multirow{3}{*}{0,841} \\
\hline & $51-60$ & 3,98 & 0,537 & & \\
\hline & $>60$ & 3,88 & 0,433 & & \\
\hline \multirow{3}{*}{ Passive } & $41-50$ & 2,03 & 0,797 & \multirow{3}{*}{ Kruskal-Wallis } & \multirow{3}{*}{0,882} \\
\hline & $51-60$ & 1,70 & 0,444 & & \\
\hline & $>60$ & 1,83 & 0,289 & & \\
\hline
\end{tabular}




\begin{tabular}{|c|c|c|c|c|c|}
\hline \multirow{3}{*}{ Leading } & $41-50$ & 4,16 & 0,669 & \multirow{3}{*}{ Kruskal-Wallis } & \multirow{3}{*}{0,342} \\
\hline & $51-60$ & 4,11 & 0,567 & & \\
\hline & $>60$ & 3,59 & 0,390 & & \\
\hline \multirow{3}{*}{ Digital } & $41-50$ & 4,24 & 0,498 & \multirow{3}{*}{ Kruskal-Wallis } & \multirow{3}{*}{$0,05^{*}$} \\
\hline & $51-60$ & 3,71 & 1,025 & & \\
\hline & $>60$ & 2,53 & 0,757 & & \\
\hline
\end{tabular}

The same picture is also shown in relation to age (Table 5). That is, the age category does not seem to affect the leadership style. The only exception is in the case of digital leadership, where the younger the respondents the more they practice the particular style $(\mathrm{p}=0.05)$.

Table 6: Leadership styles- Years of work in Tertiary Education

\begin{tabular}{|c|c|c|c|c|c|}
\hline Leadership styles & $\begin{array}{c}\begin{array}{c}\text { Years of } \\
\text { work }\end{array} \\
\end{array}$ & Mean & SD & Test & P-value \\
\hline \multirow{2}{*}{ Transformational } & $<20$ & 3,99 & 0,514 & \multirow{2}{*}{ Mann-Whitney } & \multirow{2}{*}{0,182} \\
\hline & $>20$ & 4,31 & 0,515 & & \\
\hline \multirow{2}{*}{ Trade } & $<20$ & 3,89 & 0,523 & \multirow{2}{*}{ Mann-Whitney } & \multirow{2}{*}{0,521} \\
\hline & $>20$ & 4,05 & 0,366 & & \\
\hline \multirow{2}{*}{ Passive } & $<20$ & 2,05 & 0,590 & \multirow{2}{*}{ Mann-Whitney } & \multirow{2}{*}{0,288} \\
\hline & $>20$ & 1,64 & 0,460 & & \\
\hline \multirow{2}{*}{ Leading } & $<20$ & 3,90 & 0,538 & \multirow{2}{*}{ Mann-Whitney } & \multirow{2}{*}{0,682} \\
\hline & $>20$ & 4,13 & 0,633 & & \\
\hline \multirow{2}{*}{ Digital } & $<20$ & 3,74 & 0,737 & \multirow{2}{*}{ Mann-Whitney } & \multirow{2}{*}{0,684} \\
\hline & $>20$ & 3,58 & 1,230 & & \\
\hline
\end{tabular}

Table 7: Leadership style - Job years in Management position

\begin{tabular}{|c|c|c|c|c|c|}
\hline Leadership style & $\begin{array}{c}\text { JOB } \\
\text { YEARS }\end{array}$ & Mean & SD & Test & P-value \\
\hline \multirow{2}{*}{ Transformational } & $<=6$ & 3,90 & 0,439 & \multirow{2}{*}{ Mann-Whitney } & \multirow{2}{*}{0,072} \\
\hline & $7+$ & 4,39 & 0,507 & & \\
\hline \multirow{2}{*}{ Trade } & $<=6$ & 3,77 & 0,497 & \multirow{2}{*}{ Mann-Whitney } & \multirow{2}{*}{0,094} \\
\hline & $7+$ & 4,16 & 0,297 & & \\
\hline \multirow{2}{*}{ Passive } & $<=6$ & 1,98 & 0,627 & \multirow{2}{*}{ Mann-Whitney } & \multirow{2}{*}{0,694} \\
\hline & $7+$ & 1,70 & 0,472 & & \\
\hline
\end{tabular}




\begin{tabular}{lccccc}
\hline \multirow{2}{*}{ Leading } & $<=6$ & 3,94 & 0,434 & & \\
\cline { 2 - 4 } & $7+$ & 4,10 & 0,706 & \\
\hline \multirow{2}{*}{ Digital } & $<=6$ & 3,40 & 0,945 & \multirow{2}{*}{ Mann-Whitney } & 0,694 \\
\cline { 2 - 4 } & $7+$ & 3,88 & 1,053 & & \multirow{2}{*}{0,397} \\
\hline
\end{tabular}

As regards years of service in tertiary education ((Table 6) and years of service in a post (Table 7), neither of these characteristics appears to affect the degree to which the various leadership styles are exercised.

\section{Relationship leading leadership with leadership style}

The possible relationship of several leadership styles with trade leadership is investigated with the use of coefficient correlation Pearson.

Table 8: Correlation Leading leadership with Leadership style

\begin{tabular}{lccc}
\hline & $\begin{array}{c}\text { Transformational } \\
\text { leadership }\end{array}$ & $\begin{array}{c}\text { Trade } \\
\text { leadership }\end{array}$ & $\begin{array}{c}\text { Passive to avoid } \\
\text { leadership }\end{array}$ \\
\hline Leading leadership & $\mathrm{R}^{1}$ & $\mathrm{R}^{1}$ & $\mathrm{R}^{1}$ \\
\hline
\end{tabular}

${ }^{1}$ Coefficient correlation Pearson

* Correlation sig. statistical level $p<0,05$

** Correlation sig statistical level $p<0,01$

Leadership outcome has a large positive and statistically significant correlation with transformative leadership $(\mathrm{R}=0.699)$ at a level of $\mathrm{a}=0.01$ (Table 8$)$. This means that the great degree of exercise of this leadership style coexists with the efficiency and satisfaction of leadership. On the contrary, a large negative and statistically significant correlation occurs between the Leadership Exit and the Passive - To avoid leadership. Therefore, the high degree of implementation of this style coexists with low levels of efficiency and leadership satisfaction.

The occurrence of statistically significant correlations gives the background for the application of simple linear regression in order to determine whether there is a specific dependence of the leadership outcome on each leadership style separately. The solution of multiple regression was not preferred because of the strong correlations between the independent variables.

In the following regressions, we use the leadership outcome as the dependent variable and each individual leadership style as an independent variable. The table below shows the basic parameters $\beta, \mathrm{R}^{2}$ and $\mathrm{p}$-value (Table 9). 
Table 9: Dependency Leading leadership from Leadership style

\begin{tabular}{|c|c|c|c|c|}
\hline & $\begin{array}{c}\text { Parameters of } \\
\text { Simple Linear } \\
\text { Regression }\end{array}$ & $\begin{array}{c}\text { Transformational } \\
\text { leadership }\end{array}$ & $\begin{array}{l}\text { Trading } \\
\text { leadership }\end{array}$ & $\begin{array}{l}\text { Passive to avoid } \\
\text { leadership }\end{array}$ \\
\hline \multirow{3}{*}{$\begin{array}{l}\text { Leading } \\
\text { leadership }\end{array}$} & Coefficient $\beta$ & 0,774 & 0,269 & $-0,673$ \\
\hline & p-value & $0,004^{* *}$ & 0,470 & $0,011^{*}$ \\
\hline & $\mathrm{R}^{2}$ & 0,488 & 0,041 & 0,404 \\
\hline
\end{tabular}

* Sig. statistical level $p<0,05$

** Sig statistical level $p<0,01$

As is evident, transformational leadership has a positive and statistically significant $(p=0.004<0.05)$ effect on leadership outcome, that is, the higher the implementation of this leadership style, the greater the efficiency and the satisfaction of the workers. Indeed, this particular variable interprets a large percentage of the leadership outcome variability $\left(R^{2}=0.488\right)$.

Leadership outcome is statistically significant also from Passive - To avoid leadership ( $p=0.011<0.05)$. The more leaders have passive behavior and avoid making decisions, the more resentment and inefficiency are created. This specific independent variable interprets $40.4 \%$ of the leadership outcome variability ( $R^{2}$ $=0.404)$.

As far as the Banking Leadership is concerned, it does not seem to have a statistically significant influence on the leadership outcome.

\section{Relationship of digital leadership with leadership styles}

The possible relationship of the different leadership styles with digital leadership is investigated using the Pearson correlation coefficient.

Table 10: Association of Digital Leadership with Leadership Style

\begin{tabular}{lccc}
\hline & $\begin{array}{c}\text { Transformational } \\
\text { leadership }\end{array}$ & $\begin{array}{c}\text { Trade } \\
\text { leadership }\end{array}$ & $\begin{array}{c}\text { Passive to avoid } \\
\text { leadership }\end{array}$ \\
\hline Digital Leadership & $\mathrm{R}^{1}$ & $\mathrm{R}^{1}$ & $\mathrm{R}^{1}$ \\
\hline
\end{tabular}

${ }^{1}$ Coefficient correlation Pearson

* Association is statistically important at level 0,05

Digital leadership has a large positive and statistically significant correlation with the transformational leadership $(r=0.549)$ at a level of $a=0.05$ (Table 10). This means that the high degree of exercise of this leadership style coexists with the high degree of implementation of digital leadership. 
The existence of statistically significant correlation allows us to apply simple linear regression in order to determine whether there is a specific dependence of digital leadership on each individual leadership style.

In the following regressions, we use the Digital Lead as a dependent variable, and as a stand-alone variable each Lead-style individual. The table below (Table 11) shows the basic parameters $\beta, R^{2}$ and $p$-value.

Table 11: Dependence of Digital Leadership on Leadership Style

\begin{tabular}{ll|l|l|l}
\hline $\begin{array}{l}\text { Dependent } \\
\text { variable }\end{array}$ & $\begin{array}{l}\text { Parameters of } \\
\text { Single Linear } \\
\text { Regression }\end{array}$ & $\begin{array}{l}\text { Transformational } \\
\text { leadership }\end{array}$ & $\begin{array}{l}\text { Trade } \\
\text { leadership }\end{array}$ & $\begin{array}{l}\text { Passive to avoid } \\
\text { leadership }\end{array}$ \\
\hline \multirow{2}{*}{$\begin{array}{l}\text { Digital } \\
\text { leadership }\end{array}$} & Coefficient $\beta$ & 1,047 & 1,003 & $-0,182$ \\
\cline { 2 - 5 } & p-value & $0,034^{*}$ & 0,102 & 0,723 \\
\hline $\mathrm{R}^{2}$ & 0,302 & 0,192 & 0,010 \\
\hline
\end{tabular}

${ }^{*}$ Influence is statistically significant at a level 0,05

As expected, transformational leadership has a positive and statistically significant impact $(p=0.034<0.05)$ on Digital Leadership, i.e., the greater the implementation of this leadership style, the greater the degree of Digital leadership. Indeed, this particular variable interprets a remarkable percentage of the digital leadership's volatility $\left(\mathrm{R}^{2}=0.302\right)$. With regard to Transactional and Passive Leadership, they do not appear to have statistically significant influence on the level of Digital leadership.

\section{Required digital properties}

Subsequently, the participants in the survey were asked to record the digital properties they can exploit and consider more necessary for a leader. Respondents were able to declare more than one option.

Table 12: Digital properties that can be exploited by respondents and considered necessary for a leader

\begin{tabular}{llcc}
\hline & & $\begin{array}{c}\text { FREQUENCY } \\
(\mathbf{N})\end{array}$ & $\begin{array}{c}\text { PERCENTAGE } \\
\text { (\%) }\end{array}$ \\
\hline & Social Media & 12 & 80 \\
\cline { 2 - 4 } & Mobile App & 11 & 73,3 \\
\cline { 2 - 4 } $\begin{array}{l}\text { Digital } \\
\text { characteristics }\end{array}$ & Cloud Computing & 9 & 60 \\
\cline { 2 - 4 } & Big Data & 8 & 53,3 \\
\cline { 2 - 4 } & Web Development and Tools & 8 & 53,3 \\
\cline { 2 - 4 } & Security Skills & 6 & 40 \\
\cline { 2 - 4 } & ERP Systems & 5 & 33,3 \\
\hline
\end{tabular}




\begin{tabular}{lcc} 
Digital Architecture & 4 & 26,7 \\
\hline Complex Business Systems & 3 & 20
\end{tabular}

The widespread digital properties of Social Media and Mobile App are also the ones that picked up the vast majority of responses $(80.0 \%$ and $73.3 \%$ respectively). However, the majority of respondents can take advantage of Cloud Computing (60.0\%), Big Data (53.3\%) and Web Development Tools (53.3\%). Digital Architectures and Complex Business Systems are exploitable by around $1 / 4$ of respondents (Table 12 ).

Alternatively, the number of digital properties declared by the survey participants, that they can exploit and consider important to a leader, was examined.

Table 13: Number of digital properties

\begin{tabular}{lccccc}
\hline & N & Min & Max & Mean & SD \\
\hline Number of digital properties & 15 & 1 & 9 & 4,40 & 2,798 \\
\hline
\end{tabular}

On average, respondents reported about 4 of the 9 existing properties. There were participants who declared only 1 but also participants who declared 9 (Table 13).

In order to determine whether the demographic characteristics had a statistically significant effect on the number of digital properties declared, non-parametric Mann-Whitney statistical tests were performed.

Table 14: Number of digital properties per demographic feature

\begin{tabular}{|c|c|c|c|c|c|}
\hline & $\begin{array}{r}\text { Numb } \\
\text { prc }\end{array}$ & $\begin{array}{l}\text { ligital } \\
\text { es }\end{array}$ & SD & Test & P-value \\
\hline \multirow{2}{*}{ SEX } & Male & 4,55 & 3,078 & \multirow{2}{*}{$\begin{array}{l}\text { Mann- } \\
\text { Whitney }\end{array}$} & \multirow{2}{*}{0,947} \\
\hline & Female & 4,00 & 2,160 & & \\
\hline \multirow{3}{*}{ AGE } & $41-50$ & 4,80 & 3,899 & \multirow{3}{*}{$\begin{array}{l}\text { Mann- } \\
\text { Whitney }\end{array}$} & \multirow{3}{*}{0,514} \\
\hline & $51-60$ & 4,86 & 2,410 & & \\
\hline & $>60$ & 2,67 & 1,155 & & \\
\hline \multirow{2}{*}{$\begin{array}{l}\text { Years of work in Tertiary } \\
\text { Education }\end{array}$} & $<20$ & 4,00 & 3,162 & \multirow{2}{*}{$\begin{array}{l}\text { Mann- } \\
\text { Whitney }\end{array}$} & \multirow{2}{*}{0,445} \\
\hline & $>20$ & 4,75 & 2,605 & & \\
\hline $\begin{array}{l}\text { Years of work in } \\
\text { Management Position }\end{array}$ & $<=6$ & 4,14 & 3,132 & $\begin{array}{l}\text { Mann- } \\
\text { Whitney }\end{array}$ & 0,638 \\
\hline
\end{tabular}

The results show that the demographic characteristics did not affect the number of digital properties declared by the respondents. However, participants over the age of 60 seem to have significantly less digital properties than the smaller age classes (Table 14). 
Subsequently, the relationship of the different leadership styles with the number of digital properties declared was investigated.

Table 15: Association of Digital Number with Leadership Style

\begin{tabular}{lccccc}
\hline & $\begin{array}{l}\text { Transformational } \\
\text { leadership }\end{array}$ & $\begin{array}{l}\text { Trade } \\
\text { Leadership }\end{array}$ & $\begin{array}{l}\text { Passive to } \\
\text { avoid } \\
\text { leadership }\end{array}$ & $\begin{array}{l}\text { Leading } \\
\text { leadership }\end{array}$ & $\begin{array}{l}\text { Digital } \\
\text { leadership }\end{array}$ \\
\hline & $\mathrm{R}^{1}$ & $\mathrm{R}^{1}$ & $\mathrm{R}^{1}$ & $\mathrm{R}^{1}$ & $\mathrm{R}^{1}$ \\
\hline $\begin{array}{l}\text { Number } \\
\text { digital } \\
\text { properties }\end{array}$ & 0,131 & $-0,328$ & $-0,378$ & $0,512^{*}$ & 0,304 \\
\hline $\begin{array}{l}\text { 1 Coefficient correlation Pearson } \\
\text { * Association is significant in statistic level p }<0,05\end{array}$ & & & & \\
\end{tabular}

The correlations that have emerged indicate that the number of digital properties reported by respondents is not related to the degree of exercise of the different leadership styles. In contrast, there was statistically significant positive correlation with the leadership outcome $(R=0.512)$. That is, high levels of effectiveness and satisfaction from leadership co-exist with a high number of declared digital properties (Table 15).

Finally, the variable of the number of digital properties was re-coded to highlight the percentages of respondents who stated few or many properties.

Table 16: Number of digital properties that respondents can take advantage of and consider necessary for a leader

\begin{tabular}{llcc}
\hline & & FREQUENCY & $\begin{array}{c}\text { PERCENTAGE } \\
(\mathbf{N})\end{array}$ \\
\hline $\begin{array}{l}\text { Number of digital } \\
\text { properties }\end{array}$ & $\operatorname{Low}(\mathbf{1 - 4 )}$ & 10 & 66,7 \\
\hline
\end{tabular}

Two-thirds of respondents stated a small number of digital properties that can be exploited and considered more necessary for a leader (Table 16).

Table 17: Levels of Digital Leadership per number of digital characteristics

\begin{tabular}{llllll}
\hline & \multicolumn{2}{c}{$\begin{array}{c}\text { Levels of Digital } \\
\text { Leadership }\end{array}$} & SD & Test & P-value \\
\hline $\begin{array}{l}\text { Number of digital } \\
\text { properties }\end{array}$ & $\operatorname{Low}(\mathbf{1 - 4 )}$ & 3,40 & 0,833 & $\begin{array}{c}\text { Mann- } \\
\text { Whitney }\end{array}$ & 0,129 \\
\cline { 2 - 5 } & High (7-9) & 4,16 & 1,203 & When \\
\hline
\end{tabular}

Respondents with a high number of declared digital attributes have a higher degree of digital leadership $(4,16)$ than those who have declared a low number 
$(\mu=3,40)$. However, this difference is not statistically significant $(p=0.129>$ 0.05) (Table 17).

\section{Conclusion}

E-leadership is the strategic use of digital tools in order to promote marketing plans of an enterprise. E-leadership can be beneficial at both organizational and individual levels. Similar to business, universities need to transform their practices and to keep adapting in order to be effective in the Internet-era. To conclude, the respondents are very much involved in Transformation Leadership and in Leadership Management with a slightly lower frequency. The difference in the degree of exercise of these 2 leadership styles is non-statistically significant. On the contrary, we notice that the participants in the survey avoid Passive - To avoid leadership. In fact, this style is exerted at a statistically significantly lesser degree both in relation to the Transformation and the Economic Leadership. Leadership outcome has a large positive and statistically significant correlation with transformative leadership. This means that the great degree of exercise of this leadership style coexists with the efficiency and satisfaction of leadership. On the contrary, a large negative and statistically significant correlation occurs between the Leadership Exit and the Passive - To avoid leadership. Therefore, the high degree of implementation of this style coexists with low levels of efficiency and leadership satisfaction. Digital leadership has a large positive and statistically significant correlation with the transformational leadership. This means that the high degree of exercise of this leadership style coexists with the high degree of implementation of digital leadership. Also, respondents with a high number of declared digital attributes have a higher degree of digital leadership than those who have declared a low number.

Based on the above, it seems that a successful leader implementing transformational leadership if equipped with the appropriate e-Skills will be able to be more efficient in how the administration applies to the educational institutions. In conclusion, as has been shown in practice, a person who is equipped with the appropriate e-skills is more likely to recognize and exploit the best opportunities that will be presented and which opportunities will help with the right their use in the development of the Department / University.

\section{References}

Arsenault, P. M. (2007). A case study of a university leadership seminar. Journal of Leadership Education, 6(1), 14-24. https://doi.org/10.12806/v6/i1/tf2

Barling, J., Weber, J., \& Kelloway, E. K. (1996). Effects of transformational leadership training on attitudinal and financial outcomes: A field experiment. Journal of Applied Psychology, 81(6), 827-832. https://doi.org/10.1037/0021-9010.81.6.827

Bass, B. M., \& Avolio, B. J. (2011). Multifactor Leadership Questionnaire. PsycTESTS Dataset. https://doi.org/10.1037/t03624-000

Black, S. (2015). Qualities of Effective Leadership in Higher Education. Open Journal of Leadership, 4(2), 54-66 Published Online June 2015 in SciRes. http:/ /dx.doi.org/10.4236/oj1.2015.42006. 
Bolden, R., Petrov, G., \& Gosling, J. (2008). Developing collective leadership in higher education. In H. Goreham (ed.), Research and Development Series. London: Leadership Foundation for Higher Education.

Braun, S., Nazlic, T., Weisweiler, S., Pawlowska, B., Peus, C., \& Frey, D. (2009). Effective leadeship development in higher education: individual and group level approaches. Journal of Leadership Education, 8(1), 195-206. https://doi.org/10.12806/v8/i1/ib6

Bryman, A. (2007). Effective leadership in higher education: A literature review. Studies in Higher Education, 32, 693-710. https://doi.org/10.1080/03075070701685114

Drugus, D., \& Landoy, A. (2014). Leadership in Higher Education. Bulletin of the Transilvania University of Brasov. Series V: Economic Sciences, 7(56), 2.

European Commission's Directorate General Enterprise and Industry (2012). ELeadership: Skills for Competitiveness and Innovation.

Hofmeyer, A., Sheingold, B., Klopper, H., \& Warland, J. (2015). Leadership in Learning And Teaching in Higher Education: Perspectives Of Academics In Non-Formal Leadership Roles. Contemporary Issues In Education Research, 8(3). https:// doi.org/10.19030/cier.v8i3.9348

Jenkins, D. M., \& Andenoro, A. C. (2016). Developing Critical Thinking Through Leadership Education. New Directions for Higher Education, 174, 57-67. https:// doi.org/10.1002/he.20189

Katuna, B. (2019). Effective Academic Leadership. Degendering Leadership in Higher Education, 19-61. https://doi.org/10.1108/978-1-83867-130-320191003

Lighton, J. R. B. (2018). Acquiring Useful Tools and Skills. Measuring Metabolic Rates, 232-238. https://doi.org/10.1093/oso/9780198830399.003.0020

Mahajan, S. (2011). Study on Leadership Styles and Theories. Indian Journal of Applied Research, 4(3), 281-282. doi:10.15373/2249555x/mar2014/86

Morgan, S., \& Manganaro, M. (2016). Teaching and Learning Leadership: Assessing Teams in Higher Education. The Journal of Leadership Education, 15(4), 144-152. https://doi.org/10.12806/v15/i4/a3

Pihie, Z. A. L., Sadeghi, A., \& Elias, H. (2011). Analysis of Head of Departments Leadership Styles: Implication for Improving Research University Management Practices. Procedia - Social and Behavioral Sciences, 29, 1081-1090. https:// doi.org/10.1016/j.sbspro.2011.11.341

Robinson, S., Korte, W. B., \& Hüsing, T., (2015). Acquiring e-Leadership Skills. Fostering the Digital Transformation of Europe. Brochure. Bonn.

Rybnicek, R., Leitner, K.-H., Baumgartner, L., \& Plakolm, J. (2019). Industry and leadership experiences of the heads of departments and their impact on the performance of public universities. Management Decision. https:// doi.org/10.1108/md-10-2018-1173

Samson, R. (2009). Types of Leaders and Leadership Styles. Leadership and Management in Nursing Practice and Education, 21-29. https://doi.org/10.5005/jp/books/10444_5

Shafer, A. A. (2016). Effective Approaches in Higher Education Development: A Survey in Fundraising Best Practices. In H. Alphin Jr., J. Lavine, S. Stark, \& A. Hocker (Eds.), Facilitating Higher Education Growth through Fundraising and Philanthropy (pp. 206-227). Hershey, PA: IGI Global. https:// doi.org/10.4018/978-1-4666-9664-8.ch009

Woods, P. A. (2005). Democratic Leadership in Education. London: Paul Chapman Publishing. 